\title{
Penyimpanan Serbuk Sari Jagung dan Potensinya untuk Produksi Benih Hibrida
}

\section{Pollen Storage and Its Possibility for Hybrid Seed Production of Zea mays}

\author{
Indri Fariroh ${ }^{1}$, Endah Retno Palupi ${ }^{*}$, dan Faiza Chairani Suwarno²
}

${ }^{1}$ Program Studi Ilmu dan Teknologi Benih, Sekolah Pascasarjana, Institut Pertanian Bogor

${ }^{2}$ Departemen Agronomi dan Hortikultura, Fakultas Pertanian, Institut Pertanian Bogor (Bogor Agricultural University), Jl. Meranti, Kampus IPB Darmaga, Bogor 16680, Indonesia

Diterima 28 Juni 2016/Disetujui 10 Oktober 2016

\begin{abstract}
Production of maize hybrid seed is hindered by relatively poor production by the male line pollen; short live of the pollen which was ascribed to desiccation and dehydration sensitive and flowering asynchrony between male and female lines. The aims of this study were to enhance production and viability of male line pollen and also to determine the suitable storage condition for maintaining pollen viability in order to be used for production of hybrid seed. The research consisted of two experiments. The first experiment was arranged in split plot randomized block design with NPK dosages as main plot $\left(0,300,600,900 \mathrm{~kg} \mathrm{ha}^{-1}\right)$ and application of boron as sub-plot $\left(0,1.5,3,4.5,6 \mathrm{~kg} \mathrm{ha}^{-1}\right)$, replicated three times. The second experiment used randomized block design with two factors, i.e. storage temperature $\left(-196^{\circ} \mathrm{C}\right.$ and $\left.-20^{\circ} \mathrm{C}\right)$ and storage period (0, 1, 2, 3, 4 weeks). The result showed that NPK $900 \mathrm{~kg} \mathrm{ha}^{-1}$ increased the number of spike per tassel from 9.3 to 10.7 .

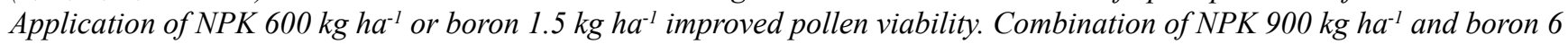
$\mathrm{kg} \mathrm{ha-1}$ resulted in the highest pollen viability of $95.3 \%$. Pollen after being stored for four weeks either in $-196{ }^{\circ} \mathrm{C}$ or $-20{ }^{\circ} \mathrm{C}$ was possible to be used for seed production with $20 \%$ seed set.
\end{abstract}

Keywords: boron, freezer, liquid nitrogen, NPK dosage, pollen viability

\section{ABSTRAK}

Kendala utama dalam produksi benih jagung hibrida adalah produksi serbuk sari tetua jantan yang rendah, periode viabel serbuk sari yang singkat karena serbuk sari jagung sensitif terhadap desikasi dan dehidrasi, serta asinkroni antara waktu mekar bunga jantan dan betina. Penelitian ini bertujuan meningkatkan produksi dan viabilitas serbuk sari galur tetua jantan, serta mendapatkan kondisi penyimpanan yang dapat memperpanjang viabilitas serbuk sari untuk digunakan dalam produksi benih hibrida. Penelitian ini terdiri atas 2 percobaan. Percobaan pertama menggunakan rancangan petak terbagi dengan rancangan lingkungan acak kelompok. Petak utama adalah dosis NPK (0, 300, 600, 900 kg ha-1) dan dosis boron sebagai anak petak $\left(0,1.5,3,4.5,6 \mathrm{~kg} \mathrm{ha}^{-1}\right)$, dengan 3 ulangan. Percobaan kedua menggunakan RAK 2 faktor, yaitu suhu penyimpanan $\left(-196{ }^{\circ} \mathrm{C}\right.$ dan $\left.-20^{\circ} \mathrm{C}\right)$ dan periode simpan $(0,1,2,3,4$ minggu). Hasil penelitian menunjukkan bahwa pemupukan NPK $900 \mathrm{~kg} \mathrm{ha}^{-1}$ meningkatkan jumlah spika per tasel dari 9.3 buah menjadi 10.7 buah. Aplikasi NPK $600 \mathrm{~kg}$ $\mathrm{ha}^{-1}$ atau dosis boron $1.5 \mathrm{~kg} \mathrm{ha} \mathrm{g}^{-1}$ dapat meningkatkan viabilitas serbuk sari jagung. Kombinasi perlakuan dosis NPK $900 \mathrm{~kg}$ ha ${ }^{-1}$ dan boron $6 \mathrm{~kg} \mathrm{ha}^{-1}$ menghasilkan viabilitas serbuk sari paling tinggi sebesar 95.3\%. Serbuk sari yang disimpan pada suhu $-196{ }^{\circ} \mathrm{C}$ dan $-20{ }^{\circ} \mathrm{C}$ selama 4 minggu dapat digunakan untuk produksi benih dengan potensi jumlah benih per tongkol sebesar $20 \%$ dari penggunaan serbuk sari segar.

Kata kunci: boron, dosis NPK, deep freezer, nitrogen cair, viabilitas serbuk sari

\section{PENDAHULUAN}

Pengelolaan serbuk sari sebagai bahan konservasi plasma nutfah sudah mulai dikembangkan karena umumnya lebih sedikit membawa penyakit dibandingkan dengan

*Penulis untuk korespondensi. e-mail: erpalupi@yahoo.co.id benih atau bagian tanaman lain (Card et al., 2007) dan tidak memerlukan ruang penyimpanan yang besar. Pengelolaan serbuk sari untuk produksi benih sudah lama dikembangkan untuk benih kelapa sawit (Lubis, 1992), sementara untuk produksi benih hibrida di Indonesia pengelolaan serbuk sari sudah dikembangkan pada Solanaceae dan Cucurbitaceae (Hermawati, 2015; Rahmi, 2016; Agustin et al., 2014; Harliani et al., 2015; Palupi et al., 2017). Pemanfaatan 
serbuk sari cabai yang telah disimpan selama 24 hari dengan viabilitas berkisar $8-9 \%$ untuk produksi benih hibrida menghasilkan fruit set berkisar 88-98\% dengan 56-6\% seed set (Simanjuntak et al., 2014).

Kendala yang sering dihadapi dalam produksi benih hibrida jagung adalah pembungaan tetua jantan dan betina yang tidak bersamaan. Apabila hal ini terjadi selama proses pemuliaan maka perakitan varietas akan terhambat. Ngugi et al. (2013) melaporkan bahwa antesis tasel pada galur inbred terjadi 2.7-4 hari sebelum rambut tongkol muncul. Oleh karena itu teknologi pengelolaan serbuk sari dapat menjadi salah satu solusi untuk mengatasi ketidak-tersediaan serbuk sari ketika dibutuhkan. Teknik penyimpanan serbuk sari yang dapat mempertahankan viabilitasnya sepanjang mungkin akan bermanfaat bagi pengembangan jagung hibrida.

Handayani (2014) melaporkan bahwa kombinasi perlakuan NPK (15-15-15) $600 \mathrm{~kg} \mathrm{ha}^{-1}$ dengan boron 3 $\mathrm{kg}$ ha $^{-1}$ pada tetua jantan jagung hibrida Bima 3 dapat meningkatkan jumlah spika per tasel, panjang spika, serta menghasilkan serbuk sari dengan viabilitas mencapai $>95 \%$ (metode pewarnaan $\mathrm{I}_{2} \mathrm{KI}$ ). Meena (2010) menyatakan bahwa boron berperan dalam perkecambahan serbuk sari, proses pembungaan dan pembuahan. Atique-ur-Rehman et al. (2014) menambahkan bahwa perlakuan priming benih padi dengan $0.1 \mathrm{mM}$ boron, aplikasi boron pada tanah dengan dosis $1 \mathrm{~kg} \mathrm{ha}^{-1}$, dan aplikasi di daun pada konsentrasi 200 $\mathrm{mM}$ boron dapat meningkatkan fertilitas malai padi dari $3.16 \%$ menjadi masing-masing 3.39\%, 3.4\%, dan 3.19\%. Teknik budidaya yang dapat meningkatkan produksi dan viabilitas serbuk sari jagung akan menunjang pengelolaan serbuk sari.

Serbuk sari jagung mempunyai periode viabel yang pendek dan sensitifterhadap desikasi dan dehidrasi. Barnabas dan Rajki (1976) melaporkan bahwa desikasi serbuk sari jagung menggunakan eksikator $\left(22^{\circ} \mathrm{C}, \mathrm{RH}<10 \%\right)$ selama 24 jam menurunkan daya berkecambah dari $85 \%$ menjadi $2 \%$. Sementara itu, perkecambahan serbuk sari jagung varietas Anjou yang dihidrasi pada suhu $22{ }^{\circ} \mathrm{C}$, RH $30-50 \%$ selama 24 jam turun dari $85 \%$ menjadi 5\%. Menurut Almeida et al. (2011) serbuk sari jagung yang dikeringkan menggunakan silika gel selama 48 jam kemudian disimpan pada suhu -20 ${ }^{\circ} \mathrm{C}$ menghasilkan perkecambahan yang lebih tinggi (72\%) jika dibandingkan dengan serbuk sari yang dikeringkan menggunakan $\mathrm{CaC}_{12} \mathrm{H}_{2} \mathrm{O}$ (57\%) setelah 30 hari simpan.

Barnabas dan Rajki (1976) melaporkan bahwa serbuk sari jagung genotip Mv 530 yang disimpan dalam nitrogen cair menghasilkan perkecambahan 5\% setelah 4 bulan simpan, dan setelah digunakan untuk produksi benih menghasilkan 5 butir per tongkol. Handayani (2014) menambahkan bahwa serbuk sari jagung tetua jantan hibrida Bima 3 yang disimpan selama 3 minggu pada suhu $-20{ }^{\circ} \mathrm{C}$ dan $-40{ }^{\circ} \mathrm{C}$ dengan viabilitas di atas $85 \%$ (dengan pewarnaan $\mathrm{I}_{2} \mathrm{KI}$ ) ketika digunakan untuk produksi benih menghasilkan 1.8 butir benih per tongkol. Hasil penelitian tersebut menunjukkan bahwa tantangan pengelolaan serbuk sari jagung bukan hanya mencari metode penyimpanan yang dapat memperpanjang periode viabel tetapi juga dapat menggambarkan potensi serbuk sari yang sudah disimpan saat digunakan dalam penyerbukan di lapangan untuk produksi benih hibrida.

\section{BAHAN DAN METODE}

Penelitian dilakukan selama 10 bulan yaitu Juni 2015 sampai dengan April 2016. Penanaman jagung dilaksanakan di Kebun Percobaan Leuwikopo, Dramaga, Bogor (240 $\mathrm{m}$ dpl). Pengolahan dan penyimpanan serta pengamatan viabilitas serbuk sari dilakukan di Laboratorium Biologi Reproduksi dan Biofisik Benih. Analisis mutu benih dilakukan di Laboratorium Analisis Mutu Benih, dan analisis tanah dilakukan di Laboratorium Pengujian, Departemen Agronomi dan Hortikultura IPB. Bahan tanaman yang digunakan adalah galur tetua jantan (Mr14) dan betina (NEI9008) jagung hibrida varietas Bima 3 dari Balai Penelitian Tanaman Serealia, Maros.

Percobaan 1. Peningkatan Produksi dan Viabilitas Serbuk Sari Jagung melalui Aplikasi NPK dan Boron

Percobaan dilaksanakan dalam rancangan petak terpisah dengan rancangan lingkungan acak kelompok dan diulang 3 kali. Petak utama adalah dosis NPK (15-1515) terdiri atas empat taraf: $0,300,600,900 \mathrm{~kg} \mathrm{ha}^{-1}$, dan anak petak adalah dosis boron $\left(\mathrm{H}_{3} \mathrm{BO}_{3}\right)$ terdiri atas lima taraf: $0,1.5,3,4.5,6 \mathrm{~kg} \mathrm{ha}^{-1}$. Tetua jantan ditanam dengan jarak $75 \mathrm{~cm}$ x $25 \mathrm{~cm}$ dengan satu benih per lubang. Boron diberikan pada 3, 5, 7 minggu setelah tanam (MST) dengan cara dilarutkan dalam air dan disiramkan pada bagian akar tanaman sesuai dengan dosis perlakuan, masing-masing sepertiga dosis aplikasi (Handayani, 2014).

Peubah yang diamati meliputi jumlah dan panjang spika per tasel, jumlah spikelet per tasel, serta viabilitas serbuk sari (diamati dengan pewarna acetocarmin 100\%, lama inkubasi dua jam). Serbuk sari dikategorikan viabel apabila berwarna merah gelap, dan non-viabel apabila berwarna merah terang atau tidak berwarna (Warid, 2009). Viabilitas serbuk sari dihitung menggunakan rumus:

$$
\text { Viabilitas }=\frac{S}{S+M} \times 100 \%
$$

dimana $\mathrm{s}=$ serbuk sari yang viabel, $\mathrm{m}=$ serbuk sari yang non-viabel. Perlakuan dosis NPK dan boron yang dapat meningkatkan produksi dan viabilitas serbuk sari jagung digunakan pada percobaan 2 .

Percobaan 2. Pengaruh Kondisi Simpan terhadap Daya Berkecambah Serbuk Sari dan Potensi Serbuk Sari yang sudah Disimpan untuk Produksi Benih

Percobaan dilaksanakan dalam rancangan acak kelompok (RAK) dua faktor, yaitu kondisi ruang simpan $\left(-196{ }^{\circ} \mathrm{C}\right.$ dan $\left.-20{ }^{\circ} \mathrm{C}\right)$ dan periode simpan $(0,1,2,3,4$ minggu), diulang 3 kali. Serbuk sari dipanen dari tetua jantan berdasarkan hasil percobaan pertama. Serbuk sari diekstrak dari beberapa tasel yang sudah mekar, kemudian digabungkan. Serbuk sari yang disimpan dalam nitrogen cair 
$\left(-196{ }^{\circ} \mathrm{C}\right)$ dan deep freezer $\left(-20^{\circ} \mathrm{C}\right)$ diambil dari gabungan hasil ekstraksi. Serbuk sari kemudian dimasukkan ke dalam cryovial dengan volume masing-masing perlakuan sebesar $1.2 \mathrm{~mL}$. Serbuk sari yang disimpan dalam deep freezer ($20{ }^{\circ} \mathrm{C}$ ) didesikasi terlebih dahulu menggunakan silika gel selama 4 jam, lalu dimasukkan ke dalam cryovial. Teknik penyimpanan pada suhu $-196{ }^{\circ} \mathrm{C}$ dilakukan berdasarkan metode penyimpanan serbuk sari mangga menurut Dutta et al. (2013), yaitu cryovial diisi serbuk sari (tanpa dikeringkan lebih dahulu), dikaitkan pada canister dan langsung direndam dalam nitrogen cair. Pada percobaan ini tidak dilakukan pengukuran suhu selama periode simpan.

Tetua betina ditanam dengan jarak tanam $75 \mathrm{~cm}$ x $20 \mathrm{~cm}$, dengan dua benih per lubang. Serbuk sari yang digunakan untuk penyerbukan adalah serbuk sari yang sudah disimpan sesuai perlakuan dan serbuk sari segar dari tetua jantan. Serbuk sari yang akan digunakan untuk uji daya berkecambah dan penyerbukan didiamkan selama 30 menit pada suhu ruang setelah dikeluarkan dari suhu -196 ${ }^{\circ} \mathrm{C}$ dan $-20{ }^{\circ} \mathrm{C}$. Penyerbukan menggunakan serbuk sari segar dilakukan pada tanggal 16 dan 17 Januari $2016(\mathrm{CH}=0-3$ $\mathrm{mm}$ per hari, $\mathrm{RH}=78-83 \%$ ). Penyerbukan menggunakan serbuk sari simpan 1, 2, 3, 4 minggu berturut-turut dilakukan pada tanggal 29 Januari $2016(\mathrm{CH}=0-3 \mathrm{~mm}$ per hari, $\mathrm{RH}$ $=83-86 \%)$, 5 Februari $2016(\mathrm{CH}=0 \mathrm{~mm}$ per hari, $\mathrm{RH}=$ 86-86.2\%), 12 Februari $2016(\mathrm{CH}=2-5 \mathrm{~mm}$ per hari, $\mathrm{RH}=$ 86-91\%) dan 19 Februari $2016(\mathrm{CH}=0 \mathrm{~mm}$ per hari, $\mathrm{RH}=$ 85-88\%). Penyerbukan dilakukan antara pukul 07.00-09.00. Penyerbukan dilakukan pada minimal 5 bunga betina untuk masing-masing perlakuan. Bunga betina sudah disungkup 3 hari sebelum penyerbukan untuk menghindari kontaminasi serbuk sari dari tanaman lain. Tongkol yang sudah diserbuki kemudian disungkup dan dilabel. Sungkup dibuka 2 hari setelah penyerbukan.

Peubah yang diamati meliputi kadar air serbuk sari (metode oven suhu tinggi $130-133^{\circ} \mathrm{C}$ selama 1 jam dengan 2 ulangan masing-masing $0.3 \mathrm{~g}$ ), daya berkecambah serbuk sari (media BK + PEG 9\% berdasarkan hasil percobaan pendahuluan, diulang 4 kali), jumlah benih per tongkol, dan bobot benih per butir dan per tongkol. Data dianalisis dengan uji F (Anova), dan apabila perlakuan berpengaruh nyata dilakukan uji lanjut dengan uji selang berganda Duncan dengan taraf nyata $(\alpha)=5 \%$.

\section{HASIL DAN PEMBAHASAN}

\section{Percobaan 1. Peningkatan Produksi dan Viabilitas Serbuk Sari Jagung Melalui Aplikasi NPK dan Boron}

Pemupukan NPK tidak mempengaruhi pertumbuhan vegetatif dan perkembangan organ reproduktif, kecuali jumlah spika per tasel. Sementara aplikasi boron meningkatkan tinggi tanaman, tetapi tidak mempengaruhi jumlah daun dan perkembangan organ reproduktif. Menurut Hardjowigeno (2007) kecukupan N untuk tanaman jagung sebesar 3\% dan boron $10 \mathrm{ppm}$. Hasil analisis tanah dari lokasi percobaan menunjukkan bahwa kandungan $\mathrm{N}$ dan boron masing-masing sebesar $0.23 \%$ dan 2.3 ppm, tergolong rendah berdasarkan kriteria yang dikemukakan Sanchez (1976). Namun demikian pemupukan NPK sampai dosis $900 \mathrm{~kg} \mathrm{ha}^{-1}$ tidak meningkatkan pertumbuhan tanaman sebagaimana ditunjukkan oleh tinggi tanaman dan jumlah daun yang tidak bertambah (Tabel 1). Data penelitian menunjukkan bahwa tinggi tanaman dan jumlah daun

Tabel 1. Pengaruh pemupukan NPK dan boron terhadap tinggi tanaman, jumlah daun, panjang spika, jumlah spika per tasel, dan jumlah spikelet per tasel tetua jantan (Mr14) jagung hibrida varietas Bima 3

\begin{tabular}{|c|c|c|c|c|c|}
\hline $\begin{array}{l}\text { Perlakuan } \\
\text { Dosis NPK }\left(\mathrm{kg} \mathrm{ha}^{-1}\right)\end{array}$ & $\begin{array}{l}\text { Tinggi tanaman } \\
\text { (cm-9 MST) }\end{array}$ & $\begin{array}{l}\text { Jumlah daun } \\
(9 \mathrm{MST})\end{array}$ & $\begin{array}{l}\text { Panjang spika } \\
(\mathrm{cm})\end{array}$ & $\begin{array}{c}\text { Jumlah spika/ } \\
\text { tasel }\end{array}$ & $\begin{array}{c}\text { Jumlah spikelet/ } \\
\text { tasel }\end{array}$ \\
\hline 0 & 110.7 & 8.3 & 28.7 & $9.3 \mathrm{c}$ & 952.9 \\
\hline 300 & 107.6 & 8.3 & 28.4 & $10.2 \mathrm{~b}$ & 1032.4 \\
\hline 600 & 121.1 & 8.3 & 29.3 & $10.3 b$ & 1026.8 \\
\hline 900 & 111.7 & 8.3 & 27.4 & $10.7 \mathrm{a}$ & 1022.2 \\
\hline Rata-rata & 112.8 & 8.3 & 28.5 & - & 1008.6 \\
\hline \multicolumn{6}{|l|}{ Dosis boron $\left(\mathrm{kg} \mathrm{ha}^{-1}\right)$} \\
\hline 0 & $115.9 \mathrm{a}$ & 8.3 & 28.1 & 10.1 & 1006.6 \\
\hline 1.5 & $110.1 \mathrm{c}$ & 8.4 & 28.5 & 9.9 & 1003.9 \\
\hline 3 & $114.6 \mathrm{ab}$ & 8.4 & 29.5 & 10.6 & 1059.2 \\
\hline 4.5 & $110.9 b c$ & 8.2 & 27.7 & 9.9 & 986.7 \\
\hline 6 & $111.2 \mathrm{bc}$ & 8.2 & 28.4 & 9.7 & 970.1 \\
\hline Rata-rata & - & 8.3 & 28.4 & 10.0 & 1005.3 \\
\hline KK (\%) & 13.6 & 23.6 & 16.6 & 23.6 & 27.2 \\
\hline
\end{tabular}

Keterangan: NPK (15-15-15), boron dalam bentuk $\mathrm{H}_{3} \mathrm{BO}_{3}$, angka yang diikuti huruf sama pada kolom yang sama tidak berbeda nyata pada uji DMRT taraf $5 \%$ 
setelah dipupuk NPK $900 \mathrm{~kg} \mathrm{ha}^{-1}$ (masing-masing $112.8 \mathrm{~cm}$ dan 8.3 helai) masih lebih rendah dari deskripsi tanaman ini (masing-masing $\pm 170 \mathrm{~cm}$ dan 12-14 helai) (Kepmentan 76/Kpts/SR.120/2/2007).

Pemupukan NPK sampai dosis $900 \mathrm{~kg} \mathrm{ha}^{-1}$ tidak meningkatkan panjang spika dan jumlah spikelet per tasel, tetapi meningkatkan jumlah spika per tasel dari rata-rata 9.3 menjadi 10.7 ( $\pm 10 \%$ ) (Tabel 1). Peningkatan organ reproduktif melalui pemupukan diduga merupakan pengaruh tidak langsung dari peningkatan pertumbuhan tanaman. Pertumbuhan tanaman yang tidak meningkat menyebabkan tidak terjadi peningkatan panjang spika dan jumlah spikelet per tasel, serta peningkatan jumlah spika per tasel yang kecil. Penelitian Handayani (2014) pada tanaman yang sama menunjukkan bahwa pupuk NPK pada dosis 300 $\mathrm{kg} \mathrm{ha}^{-1}$ dapat meningkatkan pertumbuhan tanaman (tinggi tanaman dan jumlah daun), namun peningkatan organ reproduktif sangat kecil sebagaimana ditunjukkan oleh jumlah spikelet per tasel yang meningkat dari 93.5 menjadi 95.3 buah $(1.9 \%)$.

Peningkatan satu spika per tasel (dari 9.3 menjadi 10.7) dapat diartikan sebagai peningkatan jumlah serbuk sari yang dihasilkan, karena dalam satu spika terdapat sekitar 108 spikelet (Tabel 1). Handayani (2014) melaporkan bahwa satu spikelet tetua jantan jagung varietas Bima 3 (Mr14) menghasilkan rata-rata 13.140 butir serbuk sari. Dengan demikian diperkirakan peningkatan satu spika setara dengan peningkatan jumlah serbuk sari sekitar 1.3 juta butir. Peningkatan jumlah serbuk sari tersebut akan bermanfaat jika dipanen dan disimpan untuk dapat digunakan ketika diperlukan.

Dosis boron sampai $6 \mathrm{~kg}$ ha $^{-1}$ hanya berpengaruh terhadap tinggi tanaman tetapi tidak berpengaruh terhadap jumlah daun dan perkembangan organ reproduktif (Tabel 1). Penambahan boron di atas $3 \mathrm{~kg} \mathrm{ha}^{-1}$ cenderung menurunkan perkembangan organ reproduktif sebagaimana ditunjukkan oleh jumlah spikelet per tasel. Dosis boron 4.5 dan $6 \mathrm{~kg} \mathrm{ha}^{-1}$ menghasilkan tasel yang lebih kecil dengan dinding spikelet yang lebih tebal dan kompak (Gambar 1). Menurut (Tahir et al., 2012), boron berperan dalam sintesis dinding sel. Kandungan boron yang tinggi menyebabkan penebalan dinding sel sehingga pembentukan spika dan spikelet terhambat. Patricio de Souza Lima et al. (2007) melaporkan bahwa tanaman jagung mengalami keracunan boron pada dosis 43.3 hingga $372.2 \mathrm{mg} \mathrm{kg}^{-1}$. Lordkaew et al. (2011) menambahkan bahwa jagung hibrida NS72 yang diberi boron $20 \mu \mathrm{M}$ menghasilkan anter yang lebih tebal dan kandungan boron di tasel lebih tinggi dibandingkan tanaman tanpa pemberian boron.

Tanpa pemberian NPK dan boron, viabilitas serbuk sari mencapai sekitar $87 \%$. Aplikasi boron $1.5 \mathrm{~kg} \mathrm{ha}^{-1}$ tanpa pemupukan NPK menghasilkan viabilitas serbuk sari hingga 92.3\%. Sementara itu, peningkatan dosis NPK sampai 600 $\mathrm{kg} \mathrm{ha}^{-1}$ tanpa pemberian boron menghasilkan viabilitas serbuk sari sampai $>90 \%$ (Tabel 2). Hal ini menunjukkan bahwa aplikasi pupuk NPK $600 \mathrm{~kg} \mathrm{ha}^{-1}$ dapat berfungsi sebagai substitusi pupuk boron dalam meningkatkan viabilitas serbuk sari.

Menurut Huang et al. (2000) defisiensi boron pada saat mikrosporogenesis terutama pada fase sebelum meiosis I hingga akhir tetrad (meiosis II: anafase) menghasilkan serbuk sari yang tidak sempurna, ditunjukkan dengan penurunan viabilitas (metode fluorochromatic atau FCR) dari 65\% menjadi $8 \%$. Sementara itu, penambahan boron pada tanaman menguatkan dinding sel serta perkembangan sel serbuk sari selama mikrosporogenesis sehingga menghasilkan serbuk sari yang vigor. Hasil penelitian Lordkaew et al. (2011) menunjukkan bahwa jagung hibrida NS72 yang diberi boron $20 \mu \mathrm{M}$ menghasilkan perkecambahan serbuk sari yang lebih tinggi (19.3\%) dibandingkan tanaman tanpa boron (5.5\%). Selain itu, pemberian boron pada konsentrasi 20 $\mu \mathrm{M}$ menghasilkan antera dengan dinding yang lebih tebal dibandingkan tanaman tanpa boron. Tanaman tanpa boron menghasilkan antera mengkerut dan serbuk sari kosong tanpa sitoplasma.

Pemupukan NPK $600 \mathrm{~kg} \mathrm{ha}^{-1}$ bersama dengan boron 3 $\mathrm{kgha}^{-1}$ meningkatkan viabilitas serbuk sari tetua jantan jagung hibrida Bima 3 dari 89.6\% menjadi 99.3\% menggunakan pewarna $\mathrm{I}_{2} \mathrm{KI}$ (Handayani, 2014). Proses produksi benih jagung memerlukan serbuk sari dengan viabilitas tinggi

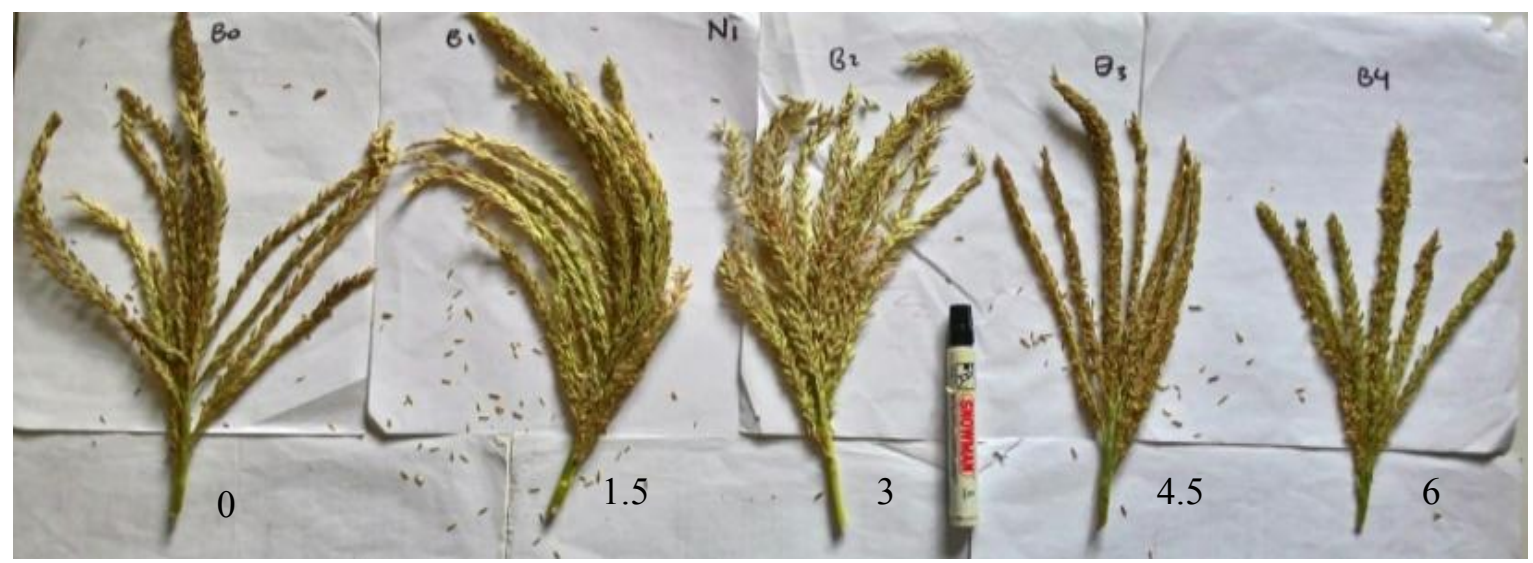

Gambar 1. Variasi morfologi tasel berdasarkan dosis boron $\left(\mathrm{kg} \mathrm{ha}^{-1}\right)$ 
Tabel 2. Pengaruh interaksi pemupukan NPK dan boron terhadap viabilitas serbuk sari jagung (\%) berdasarkan pewarna acetocarmin

\begin{tabular}{lccccc}
\hline $\begin{array}{l}\text { Dosis NPK } \\
\left(\mathrm{kg} \mathrm{ha}^{-1}\right)\end{array}$ & 0 & 1.5 & 3 & \multicolumn{5}{c}{ Dosis boron $\left(\mathrm{kg} \mathrm{ha}^{-1}\right)$} \\
\cline { 2 - 6 } & $87.7 \mathrm{~b}-\mathrm{e}$ & $92.3 \mathrm{a}-\mathrm{c}$ & $84.6 \mathrm{de}$ & $83.3 \mathrm{e}$ & $92.3 \mathrm{a}-\mathrm{c}$ \\
300 & $88.2 \mathrm{~b}-\mathrm{e}$ & $89.8 \mathrm{a}-\mathrm{d}$ & $83.4 \mathrm{e}$ & $87.9 \mathrm{~b}-\mathrm{e}$ & $87.4 \mathrm{c}-\mathrm{e}$ \\
600 & $90.2 \mathrm{a}-\mathrm{d}$ & $89.7 \mathrm{a}-\mathrm{d}$ & $93.4 \mathrm{a}-\mathrm{c}$ & $93.8 \mathrm{ab}$ & $90.4 \mathrm{a}-\mathrm{d}$ \\
900 & $91.9 \mathrm{a}-\mathrm{c}$ & $91.8 \mathrm{a}-\mathrm{c}$ & $92.3 \mathrm{a}-\mathrm{c}$ & $92.8 \mathrm{a}-\mathrm{c}$ & $95.3 \mathrm{a}$ \\
\hline
\end{tabular}

Keterangan: NPK (15-15-15), boron dalam bentuk $\mathrm{H}_{3} \mathrm{BO}_{3}$, angka yang diikuti huruf sama tidak berbeda nyata pada uji DMRT taraf 5\%; $\mathrm{KK}=10.3 \%$

untuk menjamin keberhasilan dalam penyerbukan. Serbuk sari yang viabel akan mampu membuahi sel telur dengan cepat. Kombinasi pemupukan NPK $900 \mathrm{~kg} \mathrm{ha}^{-1}$ dan boron 6 $\mathrm{kg} \mathrm{ha}^{-1}$ mampu menghasilkan viabilitas paling tinggi (Tabel 2) sehingga digunakan dalam produksi serbuk sari untuk disimpan dan kemudian digunakan dalam penyerbukan untuk produksi benih hibrida.

Percobaan 2. Pengaruh Kondisi Simpan terhadap Daya Berkecambah Serbuk Sari dan Potensi Serbuk Sari yang sudah Disimpan untuk Produksi Benih

Serbuk sari jagung yang disimpan pada suhu $-196{ }^{\circ} \mathrm{C}$ (nitrogen cair) memiliki rata-rata kadar air yang lebih tinggi (56.39\%), lebih stabil dan lebih homogen dibandingkan yang disimpan pada suhu $-20{ }^{\circ} \mathrm{C}$ (deep freezer) $(18.26 \%$ ) (Gambar 2). Serbuk sari yang disimpan pada suhu -196 ${ }^{\circ} \mathrm{C}$ adalah serbuk sari segar yang dipanen pada saat antesis dan langsung disimpan di dalam tabung nitrogen cair tanpa desikasi terlebih dahulu. Sementara itu, serbuk sari yang disimpan pada suhu $-20{ }^{\circ} \mathrm{C}$ dilakukan desikasi sebelum penyimpanan, sehingga kadar airnya lebih rendah dan lebih bervariasi.

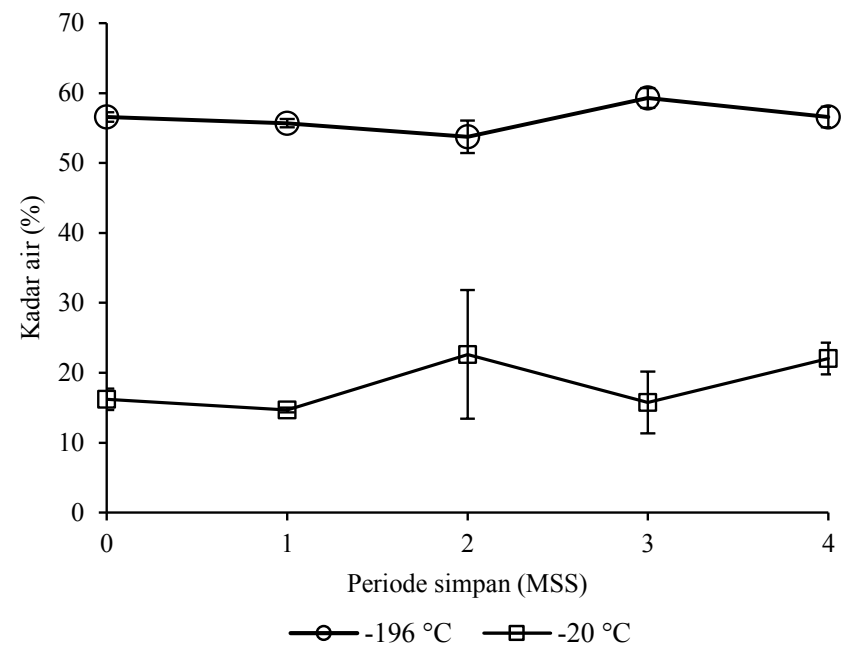

Gambar 2. Perubahan kadar air serbuk sari jagung selama penyimpanan pada suhu $-196{ }^{\circ} \mathrm{C}$ dan $-20{ }^{\circ} \mathrm{C}$; KK $=$ $9.3 \%$; MSS $=$ minggu setelah simpan
Daya berkecambah serbuk sari (pada media BK + PEG 9\%) menurun drastis setelah disimpan selama satu minggu baik pada suhu $-196{ }^{\circ} \mathrm{C}$ maupun $-20{ }^{\circ} \mathrm{C}$. Semakin lama disimpan daya berkecambah serbuk sari semakin menurun (Tabel 3). Luna et al. (2001) melaporkan bahwa daya hidup serbuk sari jagung pada suhu $28-30{ }^{\circ} \mathrm{C}, \mathrm{RH}>53 \%$ hanya selama 1-2 jam. Hasil pengamatan dalam penelitian ini menunjukkan bahwa penyimpanan pada suhu $-196{ }^{\circ} \mathrm{C}$ dapat memperpanjang daya hidup serbuk sari sampai 3 minggu, sedangkan penyimpanan pada suhu $-20{ }^{\circ} \mathrm{C}$ dapat memperpanjang sampai 4 minggu (Tabel 3).

Berdasarkan hasil penelitian Lora et al. (2006) penyimpanan serbuk sari Annona cherimola Mill. selama 3 bulan dalam nitrogen cair $\left(-196^{\circ} \mathrm{C}\right)$ dapat mempertahankan viabilitas (menggunakan media Rosell) lebih tinggi (13.6\%) daripada suhu yang lebih tinggi $\left(-20{ }^{\circ} \mathrm{C}\right)$ yaitu $10.4 \%$. Namun demikian dalam penelitian ini justru sebaliknya. Hal ini diduga waktu dan teknik pencairan serbuk sari selamat 30 menit pada suhu $18^{\circ} \mathrm{C}$ yang kurang memadai, sehingga serbuk sari yang disimpan dalam $-196{ }^{\circ} \mathrm{C}$ menghasilkan daya berkecambah yang lebih rendah.

Pencairan serbuk sari seharusnya dilakukan secara bertahap sebelum dikecambahkan. Menurut Barnabas dan Rajki (1976) pencairan serbuk sari jagung setelah disimpan pada suhu $-196{ }^{\circ} \mathrm{C}$ adalah menggunakan water bath suhu 36-37 ${ }^{\circ} \mathrm{C}$. Lora et al. (2006) menambahkan bahwa serbuk sari Annona cherimola Mill. yang disimpan dalam -196 ${ }^{\circ} \mathrm{C}$ harus dicairkan terlebih dahulu selama 5 menit di suhu ruang kemudian serbuk sari dihidrasi dalam kotak tertutup menggunakan kertas saring lembab selama 200 menit pada suhu ruang. Sementara itu dalam penelitian ini serbuk sari langsung diletakkan pada suhu ruang selama setengah jam.

Daya berkecambah serbuk sari jagung yang disimpan selama 4 minggu pada suhu $-196{ }^{\circ} \mathrm{C}$ sudah mencapai $0 \%$ sementara yang disimpan pada suhu $-20{ }^{\circ} \mathrm{C}$ sebesar $0.19 \%$, akan tetapi ketika serbuk sari tersebut diserbukkan ke tongkol yang sedang mekar dapat menghasilkan benih per tongkol masing-masing sebanyak 43.5 butir $\left(-196{ }^{\circ} \mathrm{C}\right)$ dan 53.5 butir $\left(-20^{\circ} \mathrm{C}\right)$ (Tabel 3). Hal ini menunjukkan bahwa serbuk sari jagung dapat disimpan selama 4 minggu walaupun jumlah benih per tongkol hanya mencapai $20 \%$ dari jumlah benih per tongkol yang diperoleh dengan menggunakan serbuk sari segar (234.3 butir). Namun demikian hasil ini lebih 
Tabel 3. Daya berkecambah serbuk sari, jumlah benih per tongkol, bobot benih per tongkol dan bobot benih per butir jagung hasil penyerbukan menggunakan serbuk sari yang disimpan pada suhu $-196{ }^{\circ} \mathrm{C}$ dan $-20{ }^{\circ} \mathrm{C}$

\begin{tabular}{|c|c|c|c|c|c|c|c|c|}
\hline \multirow{2}{*}{$\begin{array}{l}\text { Periode } \\
\text { simpan } \\
(\text { minggu) }\end{array}$} & \multicolumn{2}{|c|}{$\begin{array}{c}\text { DB serbuk } \\
\text { sari }(\%) \\
\end{array}$} & \multicolumn{2}{|c|}{$\begin{array}{c}\text { Jumlah } \\
\text { benih per tongkol } \\
\end{array}$} & \multicolumn{2}{|c|}{$\begin{array}{c}\text { Bobot } \\
\text { benih per tongkol }(\mathrm{g}) \\
\end{array}$} & \multicolumn{2}{|c|}{$\begin{array}{c}\text { Bobot } \\
\text { benih per butir }(\mathrm{g}) \\
\end{array}$} \\
\hline & $-196^{\circ} \mathrm{C}$ & $-20^{\circ} \mathrm{C}$ & $-196^{\circ} \mathrm{C}$ & $-20^{\circ} \mathrm{C}$ & $-196^{\circ} \mathrm{C}$ & $-20^{\circ} \mathrm{C}$ & $-196^{\circ} \mathrm{C}$ & $-20^{\circ} \mathrm{C}$ \\
\hline 0 & $23.99 a$ & $7.28 \mathrm{a}$ & $234.30 \mathrm{a}$ & $234.30 \mathrm{a}$ & $67.30 \mathrm{a}$ & $67.30 \mathrm{a}$ & $0.31 \mathrm{a}$ & $0.31 \mathrm{a}$ \\
\hline 1 & $0.84 b$ & $1.60 \mathrm{~b}$ & $0.67 \mathrm{c}$ & $0.17 \mathrm{c}$ & $0.01 \mathrm{c}$ & $0.02 \mathrm{c}$ & $0.02 \mathrm{c}$ & $0.02 \mathrm{c}$ \\
\hline 2 & $0.47 \mathrm{~b}$ & $1.16 \mathrm{~b}$ & $10.80 \mathrm{c}$ & $2.00 \mathrm{c}$ & $2.22 b c$ & $0.40 \mathrm{c}$ & $0.14 \mathrm{~b}$ & $0.04 \mathrm{c}$ \\
\hline 3 & $0.00 \mathrm{~b}$ & $0.65 b$ & $0.17 \mathrm{c}$ & $0.33 \mathrm{c}$ & $0.03 \mathrm{c}$ & $0.06 \mathrm{c}$ & $0.03 \mathrm{c}$ & $0.03 \mathrm{c}$ \\
\hline 4 & $0.00 \mathrm{~b}$ & $0.19 \mathrm{~b}$ & $43.50 \mathrm{~b}$ & $53.50 \mathrm{~b}$ & $7.19 b$ & $11.07 \mathrm{~b}$ & $0.16 \mathrm{~b}$ & $0.20 \mathrm{~b}$ \\
\hline KK (\%) & $37.60^{*}$ & $27.70 *$ & 37.70 & 34.40 & 28.90 & 30.40 & $5.80 *$ & $5.10^{*}$ \\
\hline
\end{tabular}

Keterangan: Angka yang diikuti huruf sama pada kolom yang sama tidak berbeda nyata pada uji DMRT taraf 5\%; DB= daya berkecambah; $\mathrm{KK}^{*}=$ koefisien keragaman transformasi

tinggi daripada yang dilaporkan Handayani (2014) pada varietas yang sama. Penyerbukan menggunakan serbuk sari yang telah disimpan 1, 2, dan 3 minggu dalam deep frezer $\left(-40{ }^{\circ} \mathrm{C}\right)$ masing-masing menghasilkan jumlah benih per tongkol sebesar $6.8 \%$ (13.5), 2.1\% (4.2) dan 0.9\% (1.8) dari benih yang diperoleh dengan penggunaan serbuk sari segar (197.2). Barnabas dan Rajki (1976) juga melaporkan bahwa serbuk sari jagung segar varietas Anjou yang disimpan di nitrogen cair selama 8 hari tidak menghasilkan perkecambahan dan ketika digunakan untuk penyerbukan tidak menghasilkan biji sama sekali. Kemampuan serbuk sari untuk membuahi sel telur setelah disimpan bahkan sampai satu bulan, mungkin dipengaruhi oleh pemberian pupuk NPK dan boron pada tanaman tetua jantan. Penelitian lebih rinci diperlukan untuk mengklarifikasi hal ini.

Serbuk sari segar menghasilkan bobot benih per tongkol dan bobot benih per butir yang paling tinggi. Semakin lama serbuk sari disimpan, maka bobot benih per tongkol dan per butir semakin rendah. Serbuk sari yang disimpan selama 4 minggu, baik pada suhu $-196{ }^{\circ} \mathrm{C}$ maupun $-20{ }^{\circ} \mathrm{C}$ mampu menghasilkan benih di atas 40 butir per tongkol (Tabel 3). Secara umum pembentukan benih dari penyerbukan dengan serbuk sari yang telah disimpan sangat rendah dibandingkan serbuk sari segar.

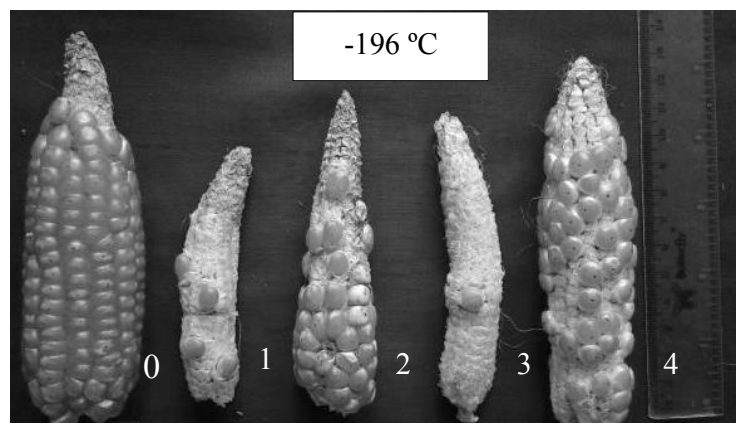

Penyerbukan dengan serbuk sari yang telah disimpan 1-3 MSS menghasilkan jumlah benih per tongkol yang sangat rendah (Gambar 3). Hal ini diduga daya berkecambah serbuk sari yang sudah menurun selama disimpan sehingga menyebabkan tabung serbuk sari gagal mencapai mikropil dan membuahi sel telur. Faktor lain yang menjadi penyebab rendahnya jumlah benih diduga karena faktor cuaca saat penyerbukan yang mempengaruhi keberhasilan pembuahan (fertilisasi).

Menurut Kaihatu dan Watkaat (2015), jagung Bima 3 menghasilkan jumlah benih per tongkol sebesar 488.3 butir pada kondisi optimum. Sementara itu pada penelitian ini penyerbukan menggunakan serbuk sari segar menghasilkan jumlah benih per tongkol yang lebih rendah yaitu 234.3 butir (Tabel 3). Hujan yang turun pada siang hari setelah penyerbukan pada pagi harinya diduga menurunkan viabilitas serbuk sari atau menyebabkan serbuk sari jatuh sehingga jumlah benih yang terbentuk rendah. Menurut Kapu dan Cosgrove (2010), penyerbukan pada tanaman jagung selesai dalam waktu 24-42 jam, sehingga hujan yang turun dalam 42 jam setelah penyerbukan berpotensi menyebabkan kegagalan penyerbukan. Selain itu, RH yang tinggi (83-91\%) selama penyerbukan menyebabkan viabilitas serbuk sari turun dimana menurut Luna et al. (2001) daya hidup serbuk sari jagung pada $\mathrm{RH}>53 \%$ hanya bertahan selama 1-2 jam.

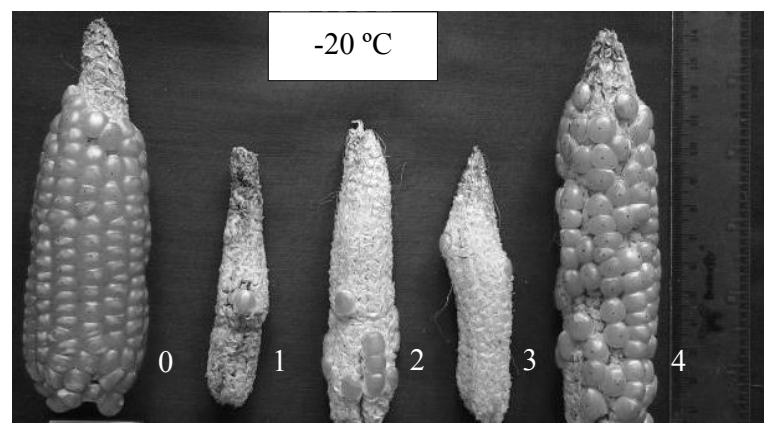

Gambar 3. Keragaan tongkol jagung hibrida Bima 3 hasil penyerbukan dengan serbuk sari yang disimpan pada $-196{ }^{\circ} \mathrm{C}$ dan $-20{ }^{\circ} \mathrm{C}(0$ : serbuk sari segar; 1: serbuk sari 1 minggu setelah simpan (MSS); 2: serbuk sari 2 MSS; 3: serbuk sari 3 MSS; 4: serbuk sari 4 MSS) 


\section{KESIMPULAN}

Pemupukan NPK $900 \mathrm{~kg} \mathrm{ha}^{-1}$ meningkatkan jumlah spika per tasel dari 9.3 buah menjadi 10.7 buah. Aplikasi NPK $600 \mathrm{~kg} \mathrm{ha}^{-1}$ atau dosis boron $1.5 \mathrm{~kg} \mathrm{ha}^{-1}$ dapat meningkatkan viabilitas serbuk sari jagung. Kombinasi perlakuan dosis NPK $900 \mathrm{~kg} \mathrm{ha}{ }^{-1}$ dan boron $6 \mathrm{~kg} \mathrm{ha}^{-1}$ menghasilkan viabilitas serbuk sari paling tinggi sebesar 95.3\%. Serbuk sari yang telah disimpan pada suhu $-196^{\circ} \mathrm{C}$ dan $-20^{\circ} \mathrm{C}$ selama 4 minggu dapat digunakan untuk produksi benih dengan potensi jumlah benih per tongkol sebesar $20 \%$ dari penggunaan serbuk sari segar.

\section{DAFTAR PUSTAKA}

Agustin, H., E.R. Palupi, M.R. Suhartanto. 2014. Pengelolaan polen untuk produksi benih melon hibrida Sunrise Meta dan Oranye Meta. J. Hortikultura 24:32-41.

Almeida, C., A.L.D. Amaral, J.F.B. Neto, M.J.C.D.M. Sereno. 2011. Conservação e germinação in vitro de pólen de milho (Zea mays subsp. mays). Rev. Bras. Bot. 34:493-497.

Atique-ur-Rehman, M. Farooq, A. Nawaz, R. Ahmad. 2014. Influence of boron nutrition on the rice productivity, kernel quality and biofortification in different production systems. Field Crops Res. 169:123-131.

Barnabas, B., E. Rajki. 1976. Storage of maize (Zea mays L.) pollen at $-196{ }^{\circ} \mathrm{C}$ in liquid nitrogen. Euphytica 25:747-752.

Card, S.D., M.N. Pearson, G.R.G. Clover. 2007. Plant pathogens transmitted by pollen. Austr. Plant Path. 36:455-461.

Dutta, S.K., M. Srivastav, R. Chaudhary, K. Lal, P. Patil, S.K. Singh, A.K. Singh. 2013. Low temperature storage of mango (Mangifera indica L.) pollen. Sci. Hort. 161:193-197.

Handayani, D.P. 2014. Peningkatan viabilitas serbuk sari jagung dengan pemupukan NPK dan boron, dan pemanfaatannya dalam produksi benih hibrida. Tesis. Sekolah Pascasarjana. Institut Pertanian Bogor. Bogor.

Hardjowigeno, S. 2007. Ilmu Tanah. CV Akademika Pressindo, Jakarta, ID.

Harliani, E.N., E.R. Palupi, D.S. Wahyudin. 2014. Potensi penyimpanan serbuk sari dalam produksi benih hibrida mentimun (Cucumis sativus L.) varietas KE014. J. Hort. Indonesia 5:104-117.
Hermawati, S. 2015. Pengeringan dan penyimpanan serbuk sari dalam produksi benih cabai hibrida IPB. Tesis. Sekolah Pascasarjana. Institut Pertanian Bogor. Bogor.

Huang, L., J. Pant, B. Dell, R.W. Bell. 2000. Effects of boron deficiency on anther development and floret fertility in wheat (Triticum aestivum L. 'Wilgoyne'). Ann. Bot. 85:493-500.

Kaihatu, S.S., F. Watkaat. 2015. Kajian adaptasi beberapa varietas unggul jagung di kabupaten Maluku Barat Daya (MBD). Agric 27:8-14.

Kapu, N.U.S., D.J. Cosgrove. 2010. Changes in growth and cell wall extensibility of maize silks following pollination. J. Exp. Bot. 61:4097-4107.

Lora, J., M.A. Pérez de Oteyza, P. Fuentetaja, J.I. Hormaza. 2006. Low temperature storage and in vitro germination of cherimoya (Annona cherimola Mill.) pollen. Sci. Hort. 108:91-94.

Lordkaew, S., B. Dell, S. Jamjod, B. Rerkasem. 2011. Boron deficiency in maize. Plant Soil 342:207-220.

Lubis, A.U. 1992. Kelapa sawit di Indonesia. Pusat Penelitian Marihat. Pematang Siantar.

Luna, V.S., M.J. Figueroa, M.B. Baltazar, L.R. Gomez, R. Townsend, J.B. Schoper. 2001. Maize pollen longevity and distance isolation requirements for effective pollen control. Crop Sci. 41:1551-1557.

Meena, R.S. 2010. Effect of boron on growth, yield and quality of tomato (Lycopersicon esculentum Mill.) cv. Pusa Ruby Grown under semi-arid conditions. Int. J. Chem. Engin. Res. 2:167-172.

Ngugi, K., J. Cheserek, C. Muchira, G. Chemining’wa. 2013. Anthesis to silking interval usefulness in developing drought tolerant maize. J. Renew. Agric. 1:84-90.

Palupi, E.R., R.M. Sidabutar, K. Wanafiah. 2017. Pollen drying and storage for hybrid seed production of cucumber (Cucumis sativus L.). Acta Hortic. 1151: 163-168.

Patricio de Souza Lima, J.C., C.W. Araujo do Nascimento, J. Guilherme da Costa Lima, Mario de Andrade Lira Junior. 2007. Critical and toxic boron levels in corn plants and soils of Pernambuco, Brazil. Rev. Bras. Ci. Solo 31:73-79.

Rahmi, M. 2016. Aplikasi boron dan pengelolaan serbuk sari untuk produksi benih cabai hibrida IPB. Tesis. Sekolah Pascasarjana. Institut Pertanian Bogor. Bogor. 
Sanchez, P.A. 1976. Properties and Management of Soils in the Tropics. New York (US): Wiley.

Sebayang, H.T., A. Suryanto, T.I.D. Kurnia. 2010. Pengaruh pemberian kayu apu (Pistia stratiotes L.) dan dosis pupuk N, P, K pada pertumbuhan dan hasil padi sawah (Oryza sativa L.). J. Agron. Indonesia 38:192198.

Simanjuntak, C., E.R. Palupi, K. Wanafiah. 2013. Penentuan media pengujian viabilitas serbuk sari cabai besar dan cabai rawit (Capsicum annuum L.). Bul. Agrohorti. 4:58-64.
Tahir, M., A. Ali, F. Khalid, M. Naeem, N. Fiaz, M. Waseem. 2012. Effect of foliar applied boron application on growth, yield and quality of maize (Zea mays L.). Pak. J. Sci. Indust. Res. 55:117-121.

Warid. 2009. Korelasi metode pengecambahan in vitro dengan pewarnaan dalam pengujian viabilitas polen. Skripsi. Program Studi Pemuliaan Tanaman dan Teknologi Benih. Institut Pertanian Bogor. Bogor. 